\title{
PERBANDINGAN PHONEGAP DAN REACT NATIVE SEBAGAI FRAMEWORK PENGEMBANGAN APLIKASI MOBILE
}

\author{
Dwi Wijonarko', Rizal Fathoni Aji² \\ Program Magister Teknik Informatika Program Pascasarjana Universitas AMIKOM Yogyakarta \\ Jl. Ring Road Utara, Condong Catur, Sleman, Yogyakarta \\ 1d.wijonarko@gmail.com, 2rizalcs@ui.ac.id
}

\begin{abstract}
Mobile application development was growing very rapidly along the increase of mobile devices and technology. One of the problems faced is the different platforms operating system on the market, it is make more difficult development process and requires a lot of cost. An application must be built at least 2 (two) types according to the current popular operating system (Android and iOS) in order to be able to get large application users.

Hybrid Application is an application development model that combines native application approach and web application to be a mobile application. It can be converted into more than one mobile operating system platform later. The advantages of hybrid applications is the rapid development process because one source code can run on more than one mobile operating system, while the disadvantage is it use more of resources than the application built with the original language of the operating system platform used.

Adobe Phonegap (Phonegap) and React Native are two frameworks that can be used to build mobile hybrid applications. In this study will be compared in terms of development and application results that run on Android devices from each framework by using case studies Aplikasi Jadwal dan Nilai pada Politeknik Kota Malang.
\end{abstract}

Keywords : mobile hybrid, Phonegap, React Native

\begin{abstract}
Abstrak
Pengembangan aplikasi berbasis perangkat bergerak (mobile) sedang mengalami peningkatan yang sangat signifikan seiring dengan peningkatan perangkat dan teknologi pendukung lainnya. Salah satu permasalahan yang dihadapi adalah perbedaan platform sistem operasi yang ada di pasaran, membuat hal ini menjadi sesuatu yang sulit dan membutuhkan banyak biaya. Sebuah aplikasi harus dibangun minimal 2 (dua) jenis sesuai sistem operasi popular saat ini (Android dan iOS) agar mampu mendapatkan pengguna yang besar.

Hybrid Application merupakan model pengembangan aplikasi yang menggabungkan pendekatan aplikasi native dan aplikasi web untuk dijadikan aplikasi mobile yang nantiya dapat dikonversi kedalam lebih dari satu platform sistem operasi mobile. Kelebihan dari aplikasi hybrid adalah proses pengembangan yang cepat dikarenakan sebuah kode program dapat dijalankan pada lebih dari satu sistem operasi mobile, sedangkan kelemahannya adalah penggunaan sumberdaya yang lebih besar dibandingkan aplikasi yang dibangun dengan bahasa asli dari platform sistem operasi yang digunakan.

Adobe Phonegap (Phonegap) dan React Native merupakan dua buah framework yang dapat digunakan untuk membangun aplikasi mobile hybrid. Dalam penelitian ini akan dibandingkan dari segi pengembangan dan hasil aplikasi yang dijalankan pada perangkat Android dari masing-masing framework dengan menggunakan studi kasus Aplikasi Jadwal dan Nilai pada Politeknik Kota Malang.
\end{abstract}

Kata kunci : mobile hybrid, Phonegap, React Native 


\section{Pendahuluan}

\subsection{Latar Belakang}

Pengembangan aplikasi perangkat bergerak (mobile application development) terus meningkat seiring munculnya perangkat bergerak yang semakin beragam. Salah satu permasalahan yang dihadapi adalah perbedaan platform sistem operasi yang ada di pasaran, membuat hal ini menjadi sesuatu yang sulit dan membutuhkan banyak biaya (Charkaoui, 2014). Sebuah aplikasi harus dibangun minimal 2 (dua) jenis sesuai sistem operasi popular saat ini (Android dan iOS) agar mampu mendapatkan pengguna yang besar.

Menurut Sokolova (2017) terdapat lebih dari 1,5 juta aplikasi yang ada di layanan Google Play Store (Juni 2015) dan pada tahun 2015 setiap hari terdapat hampir 135 juta aplikasi dipasang oleh pengguna ponsel pintar (smartphone) Android. Hal ini mengindikasikana tren pengguna aplikasi perangkat bergerak (mobile) sangat besar sehingga pengembangan aplikasi perangkat mobile khususnya sistem operasi Android masih terbuka lebar.

Hybrid Application merupakan model pengembangan aplikasi yang menggabungkan pendekatan aplikasi native dan aplikasi web untuk dijadikan aplikasi mobile (Charkaoui, 2014). Dalam pengembangannya, biasanya kode program merupakan campuran dari bahasa pemrograman native dan javascript serta HTML. Berbeda dengan penggunaan webview pada aplikasi native yang hanya mengubah HTML menjadi layaknya aplikasi native, aplikasi hybrid dapat berjalan dan melakukan proses tingkat lanjut misalnya pengaksesan perangkat kamera, GPS dan lainnya yang tidak dapat dilakukan oleh webview.

Salah satu kelemahan dari aplikasi hybrid adalah penggunaan sumberdaya khususnya memory dan CPU yang lebih besar dibandingkan aplikasi native. Hal ini dikarenakan membutuhkan proses yang lebih panjang karena harus menterjemahkan tampilan HTML atau Javascript ke dalam bentuk native. Akan tetapi keunggulan dari aplikasi hybrid ialah pengembang dapat dengan mudah membuat jenis aplikasi untuk platform yang berbeda-beda. Aplikasi hybrid tidak perlu ditulis dari awal untuk mengubah dari platform Android ke platform iOS dan sebaliknya.

Adobe Phonegap (Phonegap) dan React Native merupakan kerangka kerja / frameworks yang dapat digunakan untuk mengembangkan aplikasi mobile berbasis aplikasi hybrid. Tian
(2013) mengatakan Phonegap adalah framework yang menggunakan teknologi web untuk mewujudkan aplikasi mobile layaknya aplikasi native, seperti iPhone, Android dan sebagainya. Aplikasi dibangun dengan teknologi web seperti HTML, CSS dan Javascript dan memiliki kemampuan layaknya aplikasi native seperti kamera, media penyimpanan dan GPS. Dalam bukunya (Eisenman, 2017) mengatakan bahwa React Native adalah framework Javascript yang digunakan untuk membuat aplikasi native yang mampu berjalan di platform Android dan iOS. Framework ini berbasis React JS yang merupakan framework javascript buatan dari Facebook yang digunakan untuk membuat tampilan aplikasi yang berfokus pada aplikasi mobile.

Dalam penelitian ini akan dilihat bagaimana perbandingan pengembangan aplikasi yang dibangun menggunakan framework Phonegap dan React Native. Perbandingan ini meliputi proses kecepatan pengembangan aplikasi serta performa aplikasi yang dihasilkan.

Untuk membandingkan framework tersebut, dipilih aplikasi Penilaian dan Penjadwalan Mata Kuliah pada Politeknik Kota Malang, dalam aplikasi tersebut nantinya memiliki fitur penggunaan kamera, penulisan perangkat penyimpanan dan penampilan peta sebagai fiturfitur program yang dibandingkan. Sebagai hasil dari penelitian ini, dapat digunakan untuk bahan pertimbangan pemilihan framework dalam pengembangan aplikasi mobile hybrid yang mampu berjalan di sistem operasi Android maupun iOS.

\subsection{Perumusan Masalah}

Permasalahan dalam penelitian ini dapat dirumuskan sebagai berikut:

a. Framework manakah yang mampu menghasilkan aplikasi lebih cepat dalam pengembangan aplikasi mobile hybrid khususnya dalam aplikasi penilaian dan penjadwalan mata kuliah?

b. Seberapa signifikan penggunaan sumberdaya memori dan CPU yang dihasilkan dari aplikasi yang dibangun menggunakan React Native dibandingkan Phonegap?

\subsection{Batasan Masalah}

Batasan yang diberikan dalam penelitian ini adalah

a. Aplikasi yang dibandingkan dibangun menggunakan React Native dan Phonegap

b. Aplikasi yang dibandingkan hanya pada perangkat dengan sistem operasi Android 
c. Aplikasi yang dibandingkan adalah aplikasi Penilaian dan Penjadwalan Mata Kuliah pada Politeknik Kota Malang

d. Fitur program yang dibandingkan adalah kecepatan penampilan halaman, penggunaan kamera, penulisan perangkat penyimpanan dan penampilan peta

e. Variabel yang dibandingkan adalah kecepatan waktu pengembangan, kecepatan proses dan penggunaan sumberdaya memori serta CPU dari perangkat uji

f. Fitur aplikasi yang diujikan adalah Penampil Halaman; Kamera; Peta / Maps dan Penyimpanan (Storage)

\subsection{Tujuan Penelitian}

Tujuan yang ingin diraih dalam penelitian ini adalah:

a. Membuat sebuah aplikasi mobile Penilaian dan Penjadwalan Mata Kuliah pada Politeknik Kota Malang menggunakan framework React Native dan Phonegap.

b. Melakukan perbandingan performa dari aplikasi mobile yang dibangun menggunakan framework React Native dan Phonegap

c. Menentukan perangkat frameworks yang tepat dalam mengembangkan aplikasi mobile hybrid khususnya platform Android

\subsection{Manfaat Penelitian}

Manfaat yang diberikan dari hasil penelitian ini adalah:

a. Manfaat/kontribusi ilmiah dalam ilmu pengetahuan ialah membantu pemilihan framework yang tepat dalam membangun aplikasi mobile hybrid khususnya dalam platform Android.

b. Kegunaan atau kemampuan dari sistem yang akan diteliti ialah menghasilkan aplikasi yang lebih efisien dalam penggunaan sumberdaya serta memiliki performa yang meningkat dibandingkan aplikasi sejenis yang menggunakan framework yang berbeda

c. Manfaat yang dapat dirasakan oleh perusahaan/pemakai ialah dapat mengembangkan aplikasi mobile dalam 2 (dua) platform sistem operasi yang berbeda (Android dan iOS) dengan cepat

\section{Tinjuan Pustaka}

Beberapa penelitian sudah menyajikan perbandingan antara aplikasi mobile yang dibuat secara native dan dibuat secara hybrid maupun webapp. Dalam penelitian yang dilakukannya, Cha (2013) dalam penelitiannya menyebutkan kelebihan aplikasi hybrid adalah proses pengembangan yang cepat sehingga mampu menekan biaya pengembangan dan perawatan jangka panjang, sedangkan kekurangannya adalah bentuk tampilan yang terbatas dan tidak stabil.

Heitkötter (2013) menjelaskan secara detail perbedaan antara aplikasi web, native dan hybrid yang dibangun dengan Phonegap serta Titanium. Faktor yang dilihat adalah lingkungan pengembangan, desain antarmuka, kemudahan pengembangan aplikasi, perawatan, skalabilitas, pengembangan lanjut ; serta biaya yang diperlukan.

Oliviera (2016) mendapatkan hasil bahwa penggunaan javascript dalam aplikasi hybrid nya menggunakan sumberdaya yang lebih sedikit akan tetapi prosesnya berjalan lebih lambat dibandingkan aplikasi Java / native yang dapat berjalan lebih cepat namun menggunakan sumberdaya yang lebih banyak. Penelitian ini menggunakan metode benchmark dengan perangkat Rosetta Code dan The Computer Language Benchmark Game (TCLGB).

Novac (2016) telah membandingkan dua jenis framework penyusun aplikasi mobile hybrid yakni Xamarin dan Phonegap. Kesimpulan yang didapatkan adalah Phonegap merupakan framework yang cepat dalam proses pengembangan aplikasi mobile, tanpa harus mempelajari bahasa pemrograman yang baru. Xamarin cocok diterapkan kepada developer yang sudah memiliki latar belakang .NET karena Xamarin dibangun dengan platform yang sama.

Hansson, N., \& Vidhall, T. (2016) dalam laporan penelitiannya menyatakan kode sumber pada aplikasi yang dibangun dengan React Native dapat berjalan dengan baik tanpa terlihat perbedaan yang signifikan dibandingkan aplikasi asli, baik dari sisi tampilan maupun performa. Penelitian ini menuliskan bahwa tidak perlu melakukan perubahan yang terlalu besar apabila ingin mengubah ke platform yang lain, karena $75 \%$ kode program dapat berjalan secara langsung tanpa perlu ada konfigurasi lanjutan.

Danielsson, W. (2016) telah membuat penelitian yang membandingkan aplikasi yang dibangun dengan React Native dengan aplikasi yang dibangun menggunakan bahasa asli platform perangkat Android dan iOS. Hasil yang didapatkan adalah aplikasi tersebut tidak dapat dibedakan oleh pengguna ketika dijalankan dalam perangkat bergerak. Aplikasi dapat berjalan dengan lancar tanpa ada jeda dan perbedaan berarti. Evaluasi kinerja dilakukan untuk mengukur frekuensi GPU, beban CPU, penggunaan memori dan konsumsi daya. Hampir 
semua pengukuran menunjukkan kinerja yang lebih baik pada aplikasi Android namun perbedaannya tidak menonjol.

Penelitian-penelitian tersebut penulis ambil sebagai acuan dikarenakan tema yang diangkat memiliki kemiripan yaitu perbandingan framework pengembangan aplikasi mobile. Meskipun begitu pada bagian ini peneliti melihat kekurangan dan perbedaan yang ditemukan pada penelitian-penelitian tersebut di atas, yaitu belum ada yang melakukan penelitian tentang framework React Native serta perbandingan antara aplikasi native dengan hybrid yang menurut peneliti tidak berimbang. Aplikasi native didukung pustaka langsung dari sistem operasinya tentu akan memiliki performa yang lebih baik dibandingkan aplikasi hybrid yang harus mengubah kode awal dari HTML pada Phonegap atau Javascript pada React Native untuk menjadi layaknya aplikasi native.

Dari peneltian-penelitian yang telah disebutkan, peneliti akan mengambil tema perbandingan performa dan penggunaan sumberdaya seperti pada literature terdahulu, hanya saja menggunakan framework yang berbeda yaitu React Native dan Phonegap. React Native adalah library javascript yang dibuat oleh Facebook untuk pengembangan aplikasi mobile dan bersifat cross-platform, sedangkan Phonegap merupakan framework dari Adobe yang berkemampuan mengubah aplikasi web menjadi aplikasi mobile dan bersifat cross-platform yang memiliki banyak fitur layaknya aplikasi native.

\section{Metodologi Penelitian}

\subsection{Jenis, Sifat dan Pendekatan}

Jenis penelitian yang dilakukan adalah tindakan, peneliti akan mengumpulkan data hasil uji aplikasi dari berbagai perangkat yang dibagi menjadi 3 (tiga) kategori berdasarkan memeori dan jenis CPU nya untuk dilihat penggunaan sumberdaya ketika menjalankan aplikasi serta data jangka waktu proses pengembangan aplikasi itu sendiri.

Sifat penelitian adalah deskriptif karena penelitian ini semata-mata menggambarkan suatu objek untuk menggambil kesimpulankesimpulan yang berlaku secara umum. Dalam penelitian ini penulis akan mendeskripsikan proses pengembangan aplikasi mobile hybrid menggunakan framework yang digunakan dalam sistem informasi penilaian dan penjadwalan di Politeknik Kota Malang.

Pendekatan penelitian ini adalah bersifat kualitatif, yaitu memahami cara kerja framework yang akan dibandingkan, dan digunakan untuk membangun sebuah aplikasi yang sama dan dibandingkan pada kecepatan pengembangan serta performa pada perangkat uji aplikasi.

\subsection{Metode Pengumpulan Data}

Peneliti melakukan pengumpulan data pada penelitian ini dengan cara:

a. Peneliti melakukan observasi terhadap sistem informasi akademik yang sudah ada saat ini, khususnya sub sistem penilaian dan penjadwalan mata kuliah yang akan dibangun dalam aplikasi mobile.

b. Dalam aplikasi penilaian dan jadwal mata kuliah, fitur aplikasi yang diterapkan memiliki fungsi-fungsi yang kerap dimiliki oleh aplikasi lain. Fitur aplikasi tersebut ialah penggunaan peta (maps); penggunaan kamera; serta menulis kedalam perangkat penyimpanan (storage);

c. Data uji tentang kecepatan pengembangan meliputi waktu yang dibutuhkan dalam membangun aplikasi serta jumlah prototype aplikasi yang dihasilkan.

d. Data uji untuk menentukan performa dan kinerja dipilih berdasarkan CPU Usage, Memory Consumption dan Response Time aplikasi.

\section{Hasil dan Pembahasan}

\subsection{Hasil Aplikasi}

Berikut adalah perbandingan aplikasi yang dihasilkan, sebelah kiri adalah aplikasi yang dibangun menggunakan framework Phonegap, sedangkan sebelah kanan adalah aplikasi yang dibangun menggunakan framework React Native

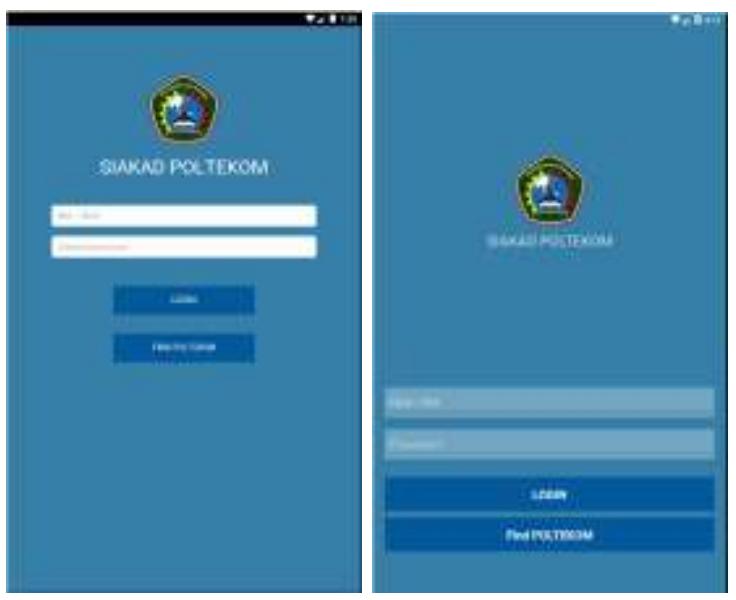

Gambar 4.1 Perbandingan tampilan awal 

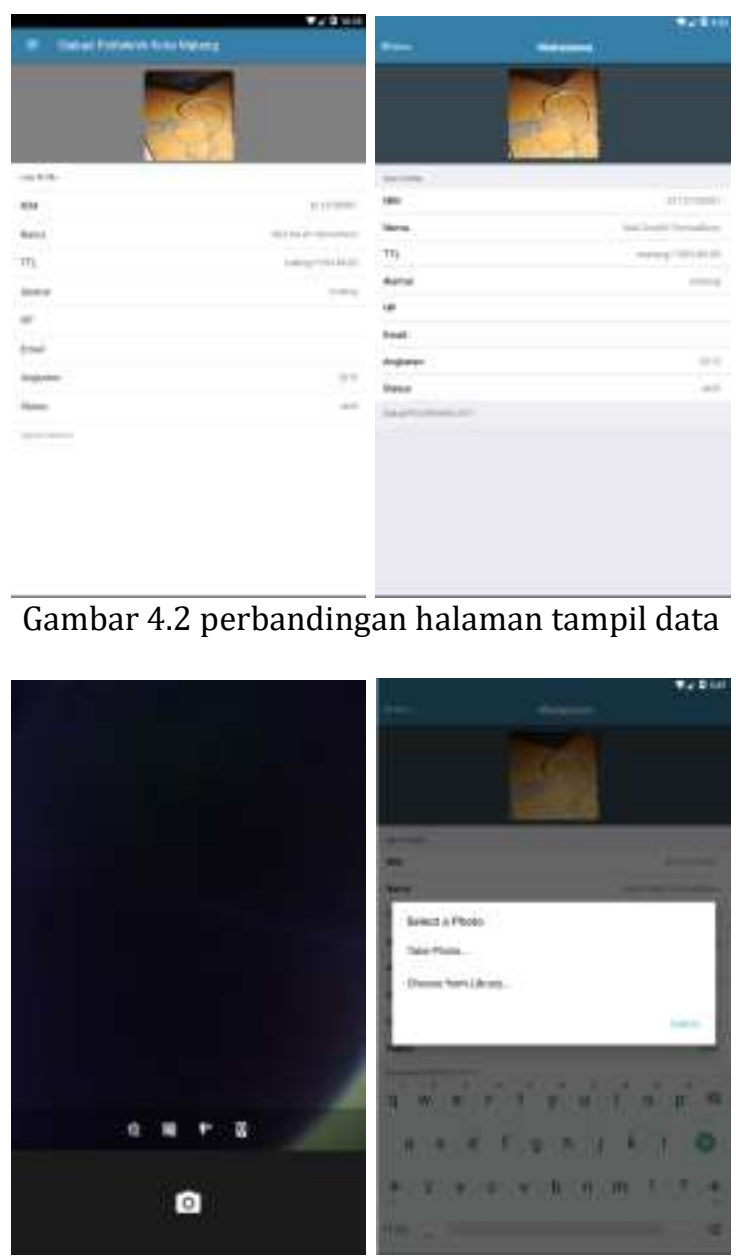

Gambar 4.3 tampilan penggunaan kamera

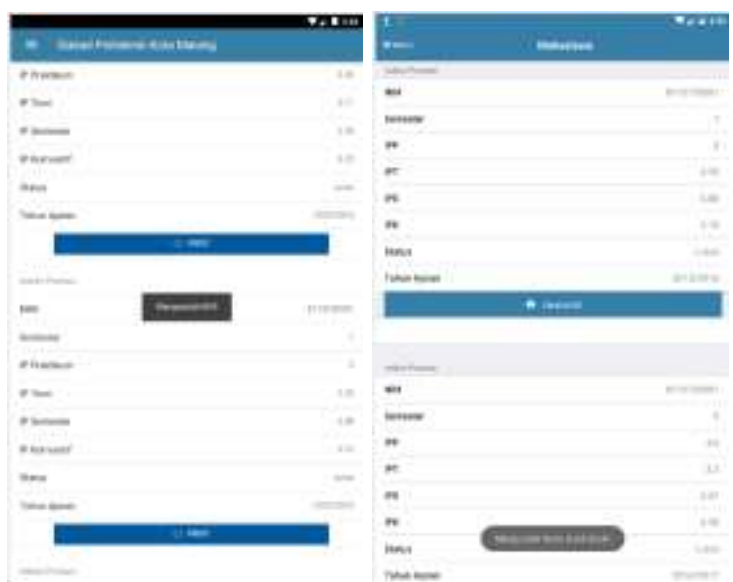

Gambar 4.4 tampilan mengkases penyimpanan

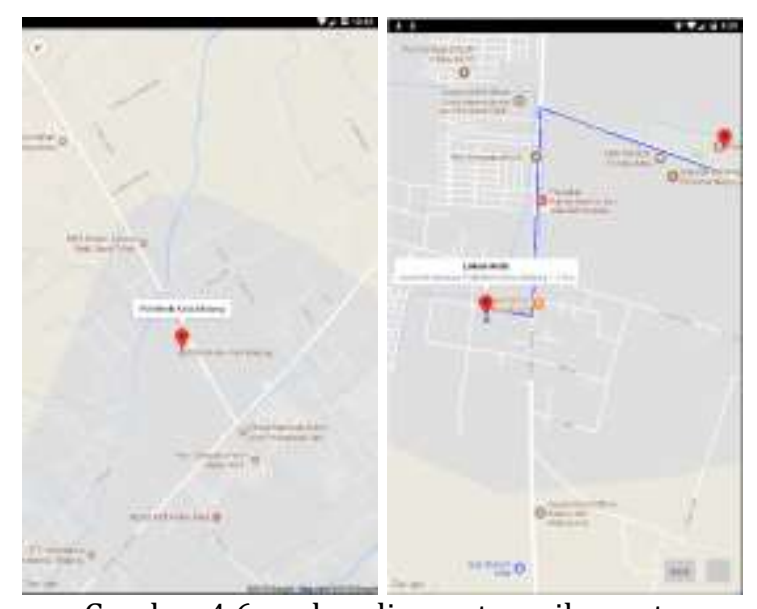

Gambar 4.6 perbandingan tampilan peta

\subsection{Grafik Perbandingan}

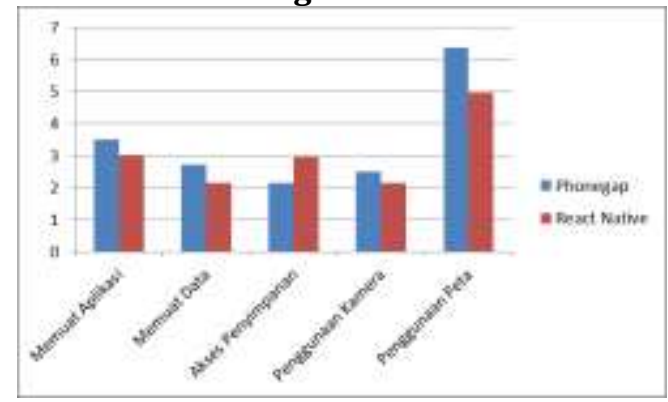

Gambar 4.7 perbandingan waktu respon

Dari gambar 4.7 terlihat waktu yang dibutuhkan untuk menjalankan tiap proses yang diujikan dan dibandingkan, aplikasi yang dibangun dengan framework Phonegap memiliki waktu proses yang lebih lama dibandungkan aplikasi yang dibangun dengan React Native, hanya pada proses akses penyimpanan, waktu yang dibutuhkan lebih cepat dibandingkan aplikasi React Native.

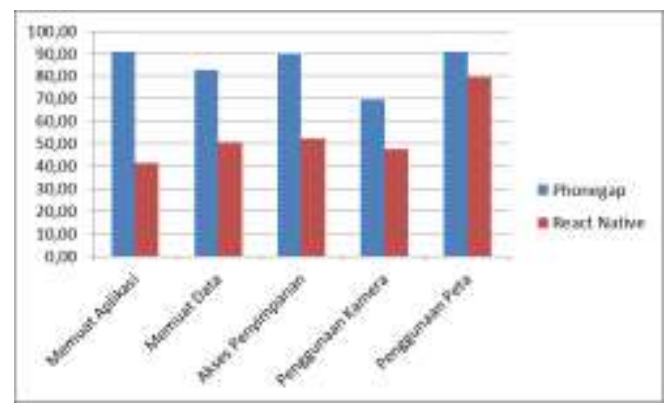

Gambar 4.8 perbandingan penggunaan memori

Rata-rata penggunaan memori dalam menjalankan aplikasi serta proses yang diujikan terlihat pada gambar 4.8. Framework Phonegap menggunakan memori yang relatih lebih besar, akan tetapi rata-rata besarannya sama tiap proses. Berbeda dengan aplikasi React Native 
yang menggunakan memori lebih sedikit tiap prosesnya.

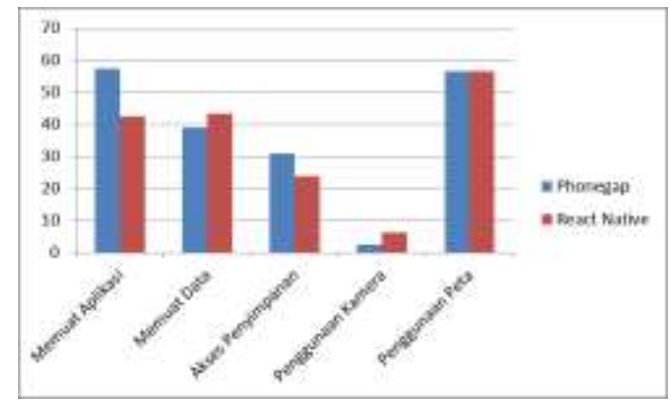

Gambar 4. 1 Perbandingan penggunaan CPU

Proses CPU yang diperlihatkan pada gambar 4.9 terlihat bahwa penggunaan CPU cenderung berbeda-beda untuk tiap proses uji. Saat memuat aplikasi dan pengaksesan penyimpanan, CPU pada aplikasi Phonegap menggunakan CPU yang lebih besar, teapi pada bagian memuat data dan penggunaan kamera, React Native menggunakan CPU yang lebih besar Sedangkan pada saat penggunakan peta, kedua aplikasi menggunakan CPU yang hampir sama.

\section{Kesimpulan dan saran}

\subsection{Kesimpulan}

Beberapa kesimpulan yang dapat dibuat setelah penelitian ini diselesaikan adalah meliputi :

a. Kedua framework yang digunakan dalam membangun aplikasi Sistem Informasi Jadwal dan Nilai - Politeknik Kota Malang menghasilkan aplikasi yang sama-sama bisa diterapkan dalam kegiatan yang behubungan dengan perkuliahan tersebut.

b. Aplikasi yang dibangun dengan Phonegap memiliki keunggulan dalam waktu pengerjaan aplikasi yang lebih singkat. Kemudahan pemahaman penggunaan sintak HTML dan Javascript menjadi nilai unggul dalam aplikasi yang dibangun menggunakan framework ini.

c. React Native menghasilkan tampilan yang lebih alami dan asli layaknya aplikasi yang dibangun dengan bahasa native Java untuk Android, sedangkan Phonegap sangat bergantung pada CSS Framework untuk tampilan aplikasinya, seperti yang dilakukan penulis menggunakan Framework7 CSS.

d. Penggunaan sumberdaya perangkat memori dan CPU dari masing-masing aplikasi hampir sama dan berimbang, khususnya pada perangkat dengan spek terbaru. Jika pada perangkat yang lama dengan spek terbatas, React Native menggunakan sumberdaya memori dan CPU yang lebih rendah.

\subsection{Saran}

Saran untuk peneliti selanjutnya yang berminat meneruskan dalam penelitian saat ini adalah perbandingan sumberdaya memori dan CPU, dalam bahasan penelitian ini, peneliti baru membandingkan dalam proses memuat aplikasi, memuat sumberdaya, menggunakan kamera serta peta dalam perangkat Android. Peneliti merasa perlu ada penelitian lanjutan yang membahas perbandingan penggunaan sumber daya perangkat dari perangkat berbasis iOS, serta proses yang lebih banyak lagi seperti penggunaan fitur multimedia dan pengaruh kecepatan koneksi yang digunakan.

\section{Daftar Pustaka:}

\section{Pustaka Buku}

Eisenman, B. 2016. Learning React Native. OReilly Media. California, United States.

Ghatol, R., \& Patel, Y. 2012. Beginning PhoneGap mobile Web Framework for JavaScript and HTML5 (1st ed.). Appress Publisher, New York City, New York, United States.

Panhale, M. (2016). Beginning hybrid mobile Application Development. Appress Publisher, New York City, New York, United States.

Pustaka Majalah, Jurnal Ilmiah atau Prosiding

\section{Pustaka Laporan Penelitian}

\section{Pustaka Elektronik}

Bouras, C., Papazois, A., \& Stasinos, N. (2014). A framework for cross-platform mobile web applications using HTML5. In Proceedings 2014 International Conference on Future Internet of Things and Cloud, FiCloud 2014 (pp. 420-424). https://doi.org/10.1109/FiCloud.2014.75

Cha, S., \& Yun, Y. (2013). Smartphone Application Development using HTML5-based CrossPlatform Framework, 7(4), 195-202. Retrieved from http://eds.b.ebscohost.com/eds/detail/deta il?vid=6\&sid=54f13d84-bf8a-4b78-ab00bc0019065efc@sessionmgr110\&hid=120\&b data=JnNpdGU9ZWRzLWxpdmU=\#db=iih\& $\mathrm{AN}=90307844$

Charkaoui, S., Adraoui, Z., \& Habib Benlahmar, E. (2014). Cross-platform mobile development approaches. Information Science and Technology (CIST), 2014 Third IEEE International Colloquium in, 188-191. 
https://doi.org/10.1109/CIST.2014.701661 6

Danielsson, W. (2016). React Native application development : A comparison between native Android and React Native (Dissertation). Retrieved from http://urn.kb.se/resolve?urn=urn:nbn:se:liu :diva-131645

Hansson, N., \& Vidhall, T. (2016). Effects on performance and usability for crossplatform application development using React Native (Dissertation). Retrieved from http://urn.kb.se/resolve?urn=urn:nbn:se:liu :diva-130022

Heitkötter, H., Hanschke, S., Majchrzak, T. A., Heitk, H., Hanschke, S., \& Majchrzak, T. A. (2013). Evaluating Cross-Platform Development Approaches for mobile Applications. In J. Cordeiro \& K.-H. Krempels (Eds.), Web Information Systems and Technologies: 8th International Conference, WEBIST 2012, Porto, Portugal, April 18-21, 2012, Revised Selected Papers (pp. 120138). Berlin, Heidelberg: Springer Berlin Heidelberg. https://doi.org/10.1007/978-3642-36608-6_8

Hui, N. M., Chieng, L. B., Ting, W. Y., Mohamed, H. H., \& Hj Mohd Arshad, M. R. (2013). Crossplatform mobile applications for android and iOS. Proceedings of 2013 6th Joint IFIP Wireless and mobile Networking Conference, WMNC 2013, 2-5. https://doi.org/10.1109/WMNC.2013.6548 969

J., P. (2014). Cross Platform Application Development With Html5 for Ios and Android Operating Systems.

Jobe, W. (2013). native Apps vs. mobile Web Apps. International Journal of Interactive mobile Technologies, 7(4), 27-33. https://doi.org/10.3991/ijim.v7i4.3226

Khandeparkar, A., Gupta, R., \& Sindhya, B. (2015). An Introduction to hybrid Platform mobile Application Development. International Journal of Computer Applications, 118(15), 31-33.

NOVAC, O. C., MARCZIN, R.-G., \& NOVAC, M. C. (2016). Comparison of Hybrid CrossPlatform Mobile Applications with Native Cross-Platform Applications. Journal of Computer Science \& Control Systems, 9(2), 24-27.
Oliveira, W., Torres, W., Castor, F., \& Ximenes, B. H. (2016). native or Web? A Preliminary Study on the Energy Consumption of Android Development Models. 2016 IEEE 23rd International Conference on Software Analysis, Evolution, and Reengineering (SANER), 1, 589-593. https://doi.org/10.1109/SANER.2016.93

Rösler, F., \& Schmietendorf, A. (2014). Towards a Mobile Application Performance Benchmark, (c), 55-59.

Redda, Y. A. (2012). Cross platform mobile Applications Development mobile Apps Mobility, (June), 1-77. Retrieved from https://daim.idi.ntnu.no/masteroppgaver/0 08/8111/masteroppgave.pdf

Smutný, P. (2012). mobile development tools and cross-platform solutions. Proceedings of the 2012 13th International Carpathian Control Conference, ICCC 2012, 653-656. https://doi.org/10.1109/CarpathianCC.201 2.6228727

Sokolova, K., Perez, C., \& Lemercier, M. (2017). Android application classification and anomaly detection with graph-based permission patterns. Decision Support Systems, $\quad 93$, 62-76. https://doi.org/10.1016/j.dss.2016.09.006

Tian, L., Du, H., Tang, L., \& Xu, Y. (2013). The discussion of cross-platform mobile application based on Phonegap. In Proceedings of the IEEE International Conference on Software Engineering and Service Sciences, ICSESS (pp. 652-655). https://doi.org/10.1109/ICSESS.2013.6615 391

Xanthopoulos, S., \& Xinogalos, S. (2013). A Comparative Analysis of Cross-platform Development Approaches for mobile Applications. Proceedings of the 6th Balkan Conference in Informatics, (June), 213-220. https://doi.org/10.1145/2490257.2490292

Zhu, X. M., Chen, D., Chen, Y., \& Chen, H. (2013). A resource integration approach for HTML5 mobile applications. Information Technology and Management, 14(3), 169181. https://doi.org/10.1007/s10799-0130158-9 